\title{
Plagues that will haunt us long after the COVID-19 pandemic is gone
}

As we struggle to gradually emerge from the horrid coronavirus disease 2019 (COVID-19) pandemic that has disrupted our lives and killed hundreds of thousands of people in the United States, we harbor the hope that life will return to "normal." But while it will certainly be a great relief to put this deadly virus behind us, many other epidemics will continue to plague our society and taint our culture.

Scientific ingenuity has led to the development of several vaccines in record time (aka "warp speed") that will help defeat the deadly scourge of COVID-19. The pandemic is likely to peter out 2 years after its onset. We will all be grateful for such a rapid resolution of the worst health crisis the world has faced in a century, which will enable medical, economic, and social recovery. But as we eventually resume our lives and rejoice in resuming the pursuit of happiness, we will quickly realize that all is not well in our society just because the viral pandemic is gone.

Perhaps the ordeal of the COVID19 pandemic, and the agony that was universally shared, will open our collective eyes to a jarring reality: many other epidemics will continue to permeate society and cause endless grief and suffering to many of our fellow humans. And thanks to our training as psychiatric physicians, we have developed extra "receptors" to the darker side of the human condition. As we help many of our psychiatric patients rendered sicker under the unbearable stress of the pandemic, we must not overlook the plight of so many others who do not show up in our clinics for health care, yet suffer enormously but imperceptibly. And no vaccine can come to the rescue of those who continue to live in quiet desperation.

\section{Long-standing epidemics}

It is truly unfortunate that many of the epidemics I am referring to have persisted for so long that they have become "fixtures" of contemporary societies. They have become "endemic epidemics" with no urgency to squelch them, as with the COVID19 pandemic. The benign neglect that perpetuates these serious epidemics has had a malignant effect of "grudging resignation" that nothing can be done to reverse them. Unlike the viral epidemic that engulfed everyone around the world and triggered a massive and unified push to defeat the virus, these long-standing epidemics continue to afflict subgroups who

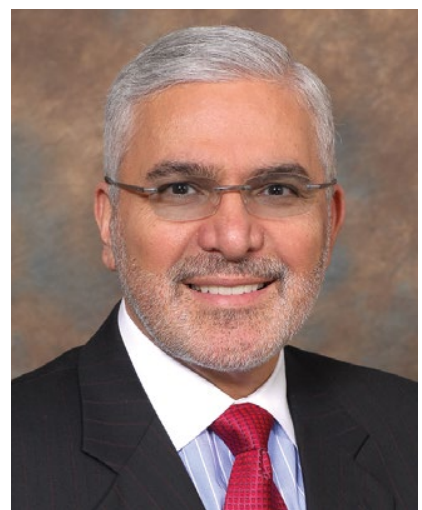

Henry A. Nasrallah, MD Editor-in-Chief doi: $10.12788 /$ cp.0088

Long-standing injurious epidemics that predated COVID-19 are likely to continue causing grief and suffering to millions, unless we diligently resolve them

To comment on this editorial or other topics of interest:

henry.nasrallah

@currentpsychiatry.com 


\section{Current}

Editorial Staff

EDITOR Jeff Bauer

SENIOR EDITOR Sathya Achia Abraham

ASSISTANT EDITOR Jason Orszt

WEB EDITOR Kathryn Wighton

Art \& Production Staff

CREATIVE DIRECTOR Louise Koenig

ART DIRECTOR Pat Fopma

DIRECTOR, JOURNAL MANUFACTURING Michael Wendt

PRODUCTION MANAGER Donna Pituras

Publishing Staff

PUBLISHER Sharon Finch

DIRECTOR EBUSINESS DEVELOPMENT

Alison Paton

SENIOR DIRECTOR OF SALES

Tim LaPella

Editor-in-Chief Emeritus

James Randolph Hillard, MD

Frontline Medical Communications

VP, SALES Mike Guire

VP, DIGITAL CONTENT \& STRATEGY

Amy Pfeiffer

PRESIDENT, CUSTOM SOLUTIONS

JoAnn Wahl

CIRCULATION DIRECTOR Jared Sonners

DIRECTOR, CUSTOM PROGRAMS

Patrick Finnegan

In affiliation with Global Academy for Medical Education, LLC

PRESIDENT David J. Small, MBA

\section{FRONTLLNE MLedge}

7 Century Drive, Suite 302

Parsippany, NJ 07054

Tel: (973) 206-3434

Fax: (973) 206-9378

www.frontlinemedcom.com

Subscription Inquiries:

subscriptions@mdedge.com are left to fend for themselves. These individuals deserve our empathy and warrant our determination to lift them from their miserable existence.

Consider some of the widespread epidemics that preceded the pandemic and will, in all likelihood, persist after the pandemic's burden is lifted:

- millions of people living in poverty and hunger

- widespread racism

- smoldering social injustice

- appalling human trafficking, especially targeting children and women

- child abuse and neglect that leads to psychosis, depression, and suicide in adulthood

- gun violence, which kills many innocent people

- domestic violence that inflicts both physical and mental harm on families

- suicide, both attempts and completions, which continues to increase annually

- the festering stigma of mental illness that adds insult to injury for psychiatric patients

- alcohol and drug addictions, which destroy lives and corrode the fabric of society

- lack of access to mental health care for millions of people who need it

- lack of parity for psychiatric disorders, which is so unjust for our patients

- venomous political hatred and hyperpartisanship, which permeates our culture and can lead to violence, as we recently witnessed

- physician burnout, due to many causes, even before the stresses of COVID-19

- the ongoing agony of wars and terrorism, including dangerous cyberattacks

- the deleterious effect of social media on everyone, especially children.

Most of these epidemics claim thousands of lives each year, and yet no concerted public health effort is being mounted to counteract them, as we are seeing with the COVID-19 pandemic. Much is being written about each of them, but there has been little tangible action, so they persist. They have become a perpetual underbelly of our society that is essentially ignored or simply given the usual lip service.

It will take a herculean effort by policymakers, the judicial system, the medical establishment, and faith organizations to put an end to these lifethreatening epidemics. It may appear too daunting to mount a war on so many fronts, but that should not deter us all from launching a strategic plan to create meaningful tactics and solutions. And just as was done with the COVID-19 pandemic, both mitigation measures as well as effective interventions must be employed in this campaign against the epidemic "hydra."

It is tragic that so many fellow humans are allowed to suffer or die while the rest of us watch, or worse, turn a blind eye and never get involved. A civilized society must never neglect so many of its suffering citizens. As psychiatrists, we are aware of those human travesties around us, but we are often so overwhelmed with our work and personal responsibilities that few of us are passionately advocating or setting aside some time for those victimized by one or more of these endemic pandemics. And unless we all decide to be actively, meaningfully involved, many lives will continue to be lost every day, but without the daily "casualty count" displayed on television screens, as is the case with COVID-19 causalities.

Regrettably, maybe that old saw is true: out of sight, out of mind.

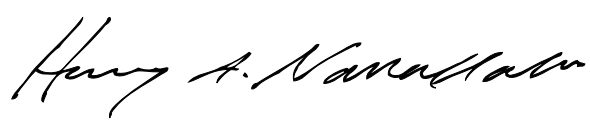

Henry A. Nasrallah, MD

Editor-in-Chief 